\title{
PATTERN OF STROKE IN AL-AZHAR UNIVERSITY HOSPITALS
}

\author{
By
Mahmoud Mohamed Abd El-Gawwad, Mohamed Al-Bahay Mohamed and Ahmed Essmat Ali

Neurology Department, Faculty of Medicine, Al-Azhar University

Corresponding author: Mahmoud Mohamed Abd El-Gawwad;

Mobile: 01019023883, E-mail: drmahmoud.ghozzy@gmail.com

\begin{abstract}
Background: The second trigger of death and the most frequent life-threatening neurological disease are now strokes. Stroke obviously ranks first of all the neurological diseases of adult life in prevalence and significance, with at least $50 \%$ of the neurological disorders in a hospitalized patient being of this type.

Objective: To study the epidemiological pattern of the cerebrovascular stroke in a sample from Al-Azhar University Hospitals including the incidence, prevalence of stroke and its different subtypes (ischemic and hemorrhagic).

Patients and Methods: A cross-sectional study was carried out on a sample from University Hospitals in AlAzhar during from 1/1/2019 to 30/12/2019. Patients complained of acute cerebrovascular stroke (ischemic and hemorrhagic stroke (including intracerebral hemorrhage (ICH) and subarachnoid hemorrhage (SAH)) were included. Patients with traumatic ICH and traumatic SAH and any patients suffering from acute neurological deficiency due to non-vascular causes such as infections or tumors have been excluded. 488 cases were diagnosed as having cerebrovascular stroke (CVS), there were 385 patients (78.9\%) of ischemic pattern and 103 patients $(21.1 \%)$ of hemorrhagic pattern.
\end{abstract}

Results: In terms of marital status, hepatic diseases, as well as side of hemiplegia, seizures (generalized more than focal), vomiting, diminished consciousness, and sphincteric disruptions, our research indicated substantial statistical differences among both study groups.

Conclusion: There were similar clinical presentations and risk factors to those reported developing and developed countries. The prevalence of stroke in Egypt is higher than in many surrounding countries.

Keywords: Stroke, Al-Azhar University Hospitals, Cerebrovascular Stroke, Ischemic.

\section{INTRODUCTION}

Cerebrovascular stroke is a syndrome with quickly evolving symptoms and focal signs, and at the time, global cerebral function loss that lasts more than twentyfour hours or leads to death with no clear cause except one of vascular origin (Abbott et al., 2017). This approach is supplemented with neuroimaging but even with advanced imaging techniques (Isaacs, 2013).

In the US, stroke is the fifth main trigger of mortality, with an average incidence of 2.6\% among 2009 and 2012 in people over 20 years of age (Ogden et al., 2012 and Mozaffarian et al., 2016).

The two broad categories of stroke hemorrhagic and ischemic are diametrically opposite conditions. 
Ischemic strokes are triggered by an interruption in the flow of blood to the brain, whereas a blood vessel collapse or an abnormal vascular structure triggers hemorrhagic strokes (Harpaz et al., 2017).

There are, sadly, variations in the probability of stroke, and the decrease has not been universal in all population subgroups. While stroke is more prevalent in males when young and middle-aged than in females (Gray et al., 2017). With lower functional results, females have a greater lifetime risk of stroke than males (Maeda et al., 2013 and GBD Lifetime Risk of Stroke Collaborators, 2018). Between 1981 and 2013, males showed a greater decrease in the age-adjusted mortality rate than females (Mozaffarian, 2016).

Approximately, $85 \%$ of strokes are ischemic (Mozaffarian et al., 2016). Moreover, $17.8 \%$ of those over 45 years of age had signs of stroke (Prentice et al., 2017) in around 6 to $28 \%$ of the population; there was a silent cerebral infarction that increased with age (Mozaffarian et al., 2016).

Globally, stroke is the second leading cause of death (Mozaffarian et al., 2016). In high-income countries, prevalence and mortality reduced among 1990 and 2010. There has been no substantial improvement in the rate of stroke deaths in low and middle-income countries. However, and the absolute number of stroke deaths has risen over that period (Krishnamurthi et al., 2013/ and Mozaffarian et al., 2016).

There are important clinical implications for the identification of the specific cause in each patient, as prognosis, acute care, and long-term recurrence prevention strategies can differ greatly for various types of cerebrovascular disease. The second most common trigger of death following coronary artery disease was stroke in 2013, accounted for 6.4 million deaths (12\% of the total). There were around 3.3 million deaths due to ischemic stroke, whereas 3.2 million deaths were due to hemorrhagic stroke (Feigin et al., 2016).

At 5 years, the risk of recurrent stroke is around $20 \%$. Both stroke occurrence and mortality have declined in the past thirty years or more. The rate of stroke decreased $40 \%$ from 1988 to 2008 in Medicare patients over 65 years of age (Feigin et al., 2016). Between 2003 and 2013, the age-adjusted stroke death rate reduced by $33.7 \%$ (Mozaffarian et al., 2016).

The repeated stroke rate is also decreasing. The annual rate of repeated stroke dropped from $8.71 \%$ in the $1960 \mathrm{~s}$ to $4.98 \%$ in the 2000 s in control patients pooled from stroke avoidance trials (Hong et al., 2011), with the present annual rate reported to be among 3\% and 4\% (Kernan et al., 2014).

A higher risk factor burden is correlated with recurrent stroke ( $F u$ et al., 2015) and enhancements in stroke avoidance over recent decades are consistent with better risk factor management, which include higher statin rates $(4 \%$ to $41.4 \%)$ and use of antihypertensive (53\% to $73.5 \%$ ) among 1992 and 2008 (Fang et al., 2014).

The purpose of this research has been to explore the epidemiological pattern of the cerebrovascular stroke in Al-Azhar university hospitals; this includes the occurrence and frequency of 
stroke and its various subtypes (ischemic and hemorrhagic).

\section{PATIENTS AND METHODS}

Study Population: A hospital based study was done on a sample from Al-Azhar university hospitals (AL Hussein and Bab Sharia hospitals).

Methods: A cross sectional study was done at the hospital level. All cases were subjected to the following: Detailed medical and neurological history, general and neurological examination, radiological investigations as: urgent brain computed tomography (CT), brain magnetic resonance image (MRI), brain magnetic resonance angiography (MRA) and brain magnetic resonance venography (MRV) according to clinical data, routine and specialized lab according to clinical data.
Inclusion criteria: Patients who complained during the period $1 / 1 / 2019$ to $30 / 12 / 2019$ of acute cerebrovascular stroke (ischemic and hemorrhagic) (including $\mathrm{ICH}$ and $\mathrm{SAH}$ ).

\section{Exclusion criteria:}

- Traumatic SAH and traumatic ICH.

- Suffering from acute neurological deficiency owing to non-vascular cause such as tumors or infections.

\section{Statistical Analysis:}

Using IBM SPSS Statistics for Windows version 22, the data were analyzed. Qualitative data was expressed as number and percentage. To compare qualitative variables, the Chi-square $\left(\chi^{2}\right)$ test and Fisher's Exact Test have been used, where necessary. In all statistical tests used in the research, a $5 \%$ level was selected as a level of significance. 


\section{RESULTS}

There were no statistically significant differences ( $\mathrm{p}$-value $>0.05$ ) among studied stroke patterns as regard sex, statistically significant differences (pvalue < 0.05) among studied stroke patterns as regard special habit and statistically significant differences (pvalue $<0.001)$ between studied stroke patterns as regard age, occupation and marital status (Table 1).

Table (1): Comparison between studied stroke patterns as regard demographic data

\begin{tabular}{|c|c|c|c|c|c|c|}
\hline \multicolumn{2}{|c|}{$\begin{array}{ll}\text { Parameters } & \text { Stroke pattern } \\
\end{array}$} & \multicolumn{2}{|c|}{$\begin{array}{l}\text { Ischemic } \\
(\mathbf{N}=385)\end{array}$} & \multicolumn{2}{|c|}{$\begin{array}{c}\text { Hemorrhagic } \\
(\mathbf{N}=\mathbf{1 0 3})\end{array}$} & \multirow{3}{*}{$\begin{array}{l}\text { P-value } \\
<0.001\end{array}$} \\
\hline \multirow{3}{*}{ Age } & $20-40$ years & 67 & $17.4 \%$ & 37 & $35.9 \%$ & \\
\hline & 40 - 60 years & 150 & $39 \%$ & 40 & $38.8 \%$ & \\
\hline & $>60$ years & 168 & $43.6 \%$ & 26 & $25.2 \%$ & \\
\hline \multirow{2}{*}{ Sex } & Male & 220 & $57.1 \%$ & 51 & $49.5 \%$ & \multirow{2}{*}{0.166} \\
\hline & Female & 165 & $42.9 \%$ & 52 & $50.5 \%$ & \\
\hline \multirow{4}{*}{ Occupation } & Manual worker & 96 & $24.9 \%$ & 18 & $17.5 \%$ & \multirow{4}{*}{$<0.001$} \\
\hline & Technical & 147 & $38.2 \%$ & 30 & $29.1 \%$ & \\
\hline & Official & 0 & $0 \%$ & 5 & $4.9 \%$ & \\
\hline & House wife & 142 & $36.9 \%$ & 50 & $48.5 \%$ & \\
\hline \multirow{3}{*}{ Marital status } & Married & 251 & $65.2 \%$ & 95 & $92.2 \%$ & \multirow{3}{*}{$<0.001$} \\
\hline & Divorced & 10 & $2.6 \%$ & 1 & $1 \%$ & \\
\hline & Widow & 124 & $32.2 \%$ & 7 & $6.8 \%$ & \\
\hline \multirow{2}{*}{ Special habit } & Smoking & 215 & $55.8 \%$ & 44 & $42.7 \%$ & \multirow{2}{*}{0.018} \\
\hline & No & 170 & $44.2 \%$ & 59 & $57.3 \%$ & \\
\hline
\end{tabular}

$\mathrm{X} 2$ : Chi-square test

There were no statistically significant differences (p-value > 0.05) among studied stroke patterns as regard memory defect and diminution of vision and statistically significant differences (pvalue $<0.05)$ among studied stroke patterns as regard impaired consciousness and diplopia (Table 2).

Table (2): Comparison between studied stroke patterns as regard CNS manifestations

\begin{tabular}{|c|c|c|c|c|c|c|}
\hline \multicolumn{2}{|c|}{$\begin{array}{ll}\text { Parameters } & \text { Stroke pattern } \\
\end{array}$} & \multicolumn{2}{|c|}{$\begin{array}{l}\text { Ischemic } \\
(\mathbf{N}=\mathbf{3 8 5})\end{array}$} & \multicolumn{2}{|c|}{$\begin{array}{l}\text { Hemorrhagic } \\
\quad(N=103)\end{array}$} & \multirow{3}{*}{$\begin{array}{r}\text { P-value } \\
0.022\end{array}$} \\
\hline \multirow{2}{*}{$\begin{array}{c}\text { Impaired } \\
\text { consciousness }\end{array}$} & Yes & 85 & $22.1 \%$ & 34 & $33 \%$ & \\
\hline & No & 300 & $77.9 \%$ & 69 & $67 \%$ & \\
\hline \multirow{2}{*}{ Memory defect } & Yes & 65 & $16.9 \%$ & 23 & $22.3 \%$ & \multirow{2}{*}{0.202} \\
\hline & No & 320 & $83.1 \%$ & 80 & $77.7 \%$ & \\
\hline \multirow{2}{*}{ Diminution of vision } & Yes & 24 & $6.2 \%$ & 7 & $6.8 \%$ & \multirow{2}{*}{0.835} \\
\hline & No & 361 & $93.8 \%$ & 96 & $93.2 \%$ & \\
\hline \multirow{2}{*}{ Diplopia } & Yes & 49 & $12.7 \%$ & 22 & $21.4 \%$ & \multirow{2}{*}{0.027} \\
\hline & No & 336 & $87.3 \%$ & 81 & $78.6 \%$ & \\
\hline
\end{tabular}

X2: Chi-square test 
There were no statistically significant differences ( $\mathrm{p}$-value > 0.05) among studied stroke patterns as regard dysarthria and dysphagia and statistically significant differences ( $\mathrm{p}$-value $<0.001)$ among studied stroke patterns as regard vomiting and seizures (Table 3).

Table (3): Comparison between studied stroke patterns as regard CNS manifestations.

\begin{tabular}{|c|c|c|c|c|c|c|}
\hline \multicolumn{2}{|c|}{$\begin{array}{l}\text { Stroke pattern } \\
\text { Parameters }\end{array}$} & \multicolumn{2}{|c|}{$\begin{array}{l}\text { Ischemic } \\
(N=385)\end{array}$} & \multicolumn{2}{|c|}{$\begin{array}{l}\text { Hemorrhagic } \\
\qquad(\mathrm{N}=\mathbf{1 0 3})\end{array}$} & P-value \\
\hline \multirow{2}{*}{ Dysarthria } & Yes & 350 & $90.9 \%$ & 96 & $93.2 \%$ & \multirow{2}{*}{0.461} \\
\hline & No & 35 & $9.1 \%$ & 7 & $6.8 \%$ & \\
\hline \multirow{2}{*}{ Dysphagia } & Yes & 100 & $26 \%$ & 26 & $25.2 \%$ & \multirow{2}{*}{0.880} \\
\hline & No & 285 & $74 \%$ & 77 & $74.8 \%$ & \\
\hline \multirow{2}{*}{ Vomiting } & Yes & 114 & $29.6 \%$ & 68 & $66 \%$ & \multirow{2}{*}{$<0.001$} \\
\hline & No & 271 & $70.4 \%$ & 35 & $34 \%$ & \\
\hline \multirow{2}{*}{ Seizures } & Yes & 93 & $24.2 \%$ & 43 & $41.7 \%$ & \multirow{2}{*}{$<0.001$} \\
\hline & No & 292 & $75.8 \%$ & 60 & $58.3 \%$ & \\
\hline
\end{tabular}

X2: Chi-square test

There were no statistically significant differences ( $\mathrm{p}$-value $>0.05$ ) among studied stroke patterns as regard facial palsy, tinnitus and vertigo and statistically significant differences ( $\mathrm{p}$-value $<0.001$ ) among studied stroke patterns as regard headache (Table 4).

Table (4): Comparison between studied stroke patterns as regard CNS manifestations

\begin{tabular}{|c|c|c|c|c|c|c|}
\hline \multicolumn{2}{|c|}{$\begin{array}{l}\text { Stroke pattern } \\
\text { Parameters }\end{array}$} & \multicolumn{2}{|c|}{$\begin{array}{l}\text { Ischemic } \\
(\mathbf{N}=\mathbf{3 8 5}) \\
\end{array}$} & \multicolumn{2}{|c|}{$\begin{array}{c}\text { Hemorrhagic } \\
(\mathbf{N}=103)\end{array}$} & P-value \\
\hline \multirow{2}{*}{ Headache } & Yes & 226 & $58.7 \%$ & 80 & $77.7 \%$ & \multirow{2}{*}{$<0.001$} \\
\hline & No & 159 & $41.3 \%$ & 23 & $22.3 \%$ & \\
\hline \multirow{2}{*}{ Facial palsy } & Yes & 340 & $88.3 \%$ & 92 & $89.3 \%$ & \multirow{2}{*}{0.775} \\
\hline & No & 45 & $11.7 \%$ & 11 & $10.7 \%$ & \\
\hline \multirow{2}{*}{ Tinnitus } & Yes & 50 & $13 \%$ & 7 & $6.8 \%$ & \multirow{2}{*}{0.082} \\
\hline & No & 335 & $87 \%$ & 96 & $93.2 \%$ & \\
\hline \multirow{2}{*}{ Vertigo } & Yes & 45 & $11.7 \%$ & 12 & $11.7 \%$ & \multirow{2}{*}{0.992} \\
\hline & No & 340 & $88.3 \%$ & 91 & $88.3 \%$ & \\
\hline
\end{tabular}

$\mathrm{X} 2$ : Chi-square test

There were no statistically significant differences ( $\mathrm{p}$-value $>0.05$ ) among studied stroke patterns as regard bulbar paralysis and hypoglossal paralysis, statistically significant differences (pvalue < 0.05) among studied stroke patterns as regard hemiparesis or hemiplegia and statistically significant differences ( $\mathrm{p}$-value $<0.001$ ) among studied stroke patterns as regard site of hemiparesis/ hemiplegia (Table 5). 
Table (5): Comparison between studied stroke patterns as regard CNS manifestations

\begin{tabular}{|c|c|c|c|c|c|c|}
\hline \multirow{2}{*}{ Parameters } & \multicolumn{2}{|c|}{$\begin{array}{c}\text { Ischemic } \\
(\mathbf{N = 3 8 5})\end{array}$} & \multicolumn{2}{c|}{$\begin{array}{c}\text { Hemorrhagic } \\
(\mathbf{N = 1 0 3})\end{array}$} & \multirow{2}{*}{ P-value } \\
\hline \multirow{2}{*}{ Bulbar paralysis } & Yes & 145 & $37.7 \%$ & 34 & $33 \%$ & \multirow{2}{*}{0.384} \\
\cline { 2 - 7 } & No & 240 & $62.3 \%$ & 69 & $67 \%$ & \\
\hline \multirow{2}{*}{ Hypoglossal paralysis } & Yes & 339 & $88.1 \%$ & 92 & $89.3 \%$ & \multirow{2}{*}{0.722} \\
\cline { 2 - 7 } & No & 46 & $11.9 \%$ & 11 & $10.7 \%$ & \\
\hline \multirow{2}{*}{$\begin{array}{c}\text { Hemiparesis or } \\
\text { hemiplegia }\end{array}$} & Yes & 371 & $96.4 \%$ & 92 & $89.3 \%$ & \multirow{2}{*}{$\mathbf{0 . 0 0 4}$} \\
\cline { 2 - 6 } Site of hemiplegia & No & 14 & $3.6 \%$ & 11 & $10.7 \%$ & \\
\cline { 2 - 6 } & Right & 236 & $61.3 \%$ & 38 & $36.9 \%$ & \multirow{2}{*}{$\mathbf{0 . 0 0 1}$} \\
\hline
\end{tabular}

X2: Chi-square test

There were statistically significant differences (p-value $<0.05$ ) among studied stroke patterns as regard hemihypothesia and gait disturbances and statistically significant differences (pvalue < 0.001) among studied stroke patterns as regard Sphinctric disturbances (Table 6).

Table (6): Comparison between studied stroke patterns as regard CNS manifestations

\begin{tabular}{|c|c|c|c|c|c|c|}
\hline \multicolumn{2}{|c|}{$\begin{array}{ll}\text { Parameters } & \text { Stroke pattern } \\
\end{array}$} & \multicolumn{2}{|c|}{$\begin{array}{l}\text { Ischemic } \\
(\mathbf{N}=\mathbf{3 8 5})\end{array}$} & \multicolumn{2}{|c|}{$\begin{array}{l}\text { Hemorrhagic } \\
\quad(N=103)\end{array}$} & P-value \\
\hline \multirow{2}{*}{ Hemi-hypothesia } & Yes & 44 & $11.4 \%$ & 23 & $22.3 \%$ & \multirow{2}{*}{0.004} \\
\hline & No & 341 & $88.6 \%$ & 80 & $77.7 \%$ & \\
\hline \multirow{2}{*}{ Gait disturbances } & Yes & 332 & $86.2 \%$ & 76 & $73.8 \%$ & \multirow{2}{*}{0.002} \\
\hline & No & 53 & $13.8 \%$ & 27 & $26.2 \%$ & \\
\hline \multirow{2}{*}{$\begin{array}{c}\text { Sphinctric } \\
\text { disturbances }\end{array}$} & Yes & 119 & $30.9 \%$ & 56 & $54.4 \%$ & \multirow{2}{*}{$<0.001$} \\
\hline & No & 266 & $69.1 \%$ & 47 & $45.6 \%$ & \\
\hline
\end{tabular}

X2: Chi-square test

There were no statistically significant differences ( $\mathrm{p}$-value $>0.05$ ) among studied stroke patterns as regard hyperlipidemia, renal disease, cardiac disease \& HTN, statistically significant differences (p-value $<0.05)$ among studied stroke patterns as regard DM and statistically significant differences (pvalue < 0.001) among studied stroke patterns as regard liver disease (Table 7). 
Table (7): Comparison between studied stroke patterns as regard risk factors

\begin{tabular}{|c|c|c|c|c|c|c|}
\hline \multicolumn{2}{|c|}{$\begin{array}{l}\text { Stroke pattern } \\
\text { Parameters }\end{array}$} & \multicolumn{2}{|c|}{$\begin{array}{l}\text { Ischemic } \\
(\mathbf{N}=385)\end{array}$} & \multicolumn{2}{|c|}{$\begin{array}{l}\text { Hemorrhagic } \\
(\mathrm{N}=\mathbf{1 0 3})\end{array}$} & P-value \\
\hline \multirow{2}{*}{ Hyperlipidemia } & Yes & 44 & $11.4 \%$ & 11 & $10.7 \%$ & \multirow[b]{2}{*}{0.831} \\
\hline & No & 341 & $88.6 \%$ & 92 & $89.3 \%$ & \\
\hline \multirow{2}{*}{ Renal dis. } & Yes & 5 & $1.3 \%$ & 1 & $1 \%$ & \multirow{2}{*}{0.789} \\
\hline & No & 380 & $98.7 \%$ & 102 & $99 \%$ & \\
\hline \multirow{2}{*}{ Cardiac dis. } & Yes & 92 & $23.9 \%$ & 17 & $16.5 \%$ & \multirow{2}{*}{0.110} \\
\hline & No & 293 & $76.1 \%$ & 86 & $83.5 \%$ & \\
\hline \multirow{2}{*}{ DM } & Yes & 205 & $53.2 \%$ & 42 & $40.8 \%$ & \multirow{2}{*}{0.025} \\
\hline & No & 180 & $46.8 \%$ & 61 & $59.2 \%$ & \\
\hline \multirow{2}{*}{ HTN } & Yes & 220 & $57.1 \%$ & 67 & $65 \%$ & \multirow{2}{*}{0.148} \\
\hline & No & 165 & $42.9 \%$ & 36 & $35 \%$ & \\
\hline \multirow{2}{*}{ Liver dis. } & Yes & 0 & $0 \%$ & 11 & $10.7 \%$ & \multirow{2}{*}{$<0.001$} \\
\hline & No & 385 & $100 \%$ & 92 & $89.3 \%$ & \\
\hline
\end{tabular}

$\mathrm{X} 2$ : Chi-square test

There were statistically significant differences ( $\mathrm{p}$-value $<0.001)$ among studied stroke patterns as regard time between symptom and start of treatment (Table 8).

Table (8): Comparison between studied stroke patterns as regard time between symptom and start of treatment

\begin{tabular}{|c|c|c|c|c|c|c|}
\hline \multicolumn{2}{|c|}{$\begin{array}{l}\text { Stroke pattern } \\
\text { Parameters }\end{array}$} & \multicolumn{2}{|c|}{$\begin{array}{l}\text { Ischemic } \\
(\mathbf{N}=385)\end{array}$} & \multicolumn{2}{|c|}{$\begin{array}{l}\text { Hemorrhagic } \\
(\mathrm{N}=\mathbf{1 0 3})\end{array}$} & P-value \\
\hline \multirow{3}{*}{ Time } & $<4$ hours & 13 & $3.4 \%$ & 12 & $11.7 \%$ & \multirow{3}{*}{$<0.001$} \\
\hline & $4-8$ hours & 36 & $9.4 \%$ & 2 & $1.9 \%$ & \\
\hline & $>8$ hours & 336 & $87.3 \%$ & 89 & $86.4 \%$ & \\
\hline
\end{tabular}

X2: Chi-square test

There were statistically significant differences (p-value $<0.05)$ among studied stroke patterns as regard history of similar conditions in the family (Table 9).

Table (9): Comparison between studied stroke patterns as regard history of similar conditions in the family

\begin{tabular}{|c|c|c|c|c|c|c|}
\hline \multicolumn{2}{|c|}{ Stroke pattern } & \multicolumn{2}{c|}{$\begin{array}{c}\text { Ischemic } \\
(\mathbf{N = 3 8 5})\end{array}$} & \multicolumn{2}{c|}{$\begin{array}{c}\text { Hemorrhagic } \\
(\mathbf{N}=\mathbf{1 0 3})\end{array}$} & $\begin{array}{c}\text { P- } \\
\text { value }\end{array}$ \\
\hline $\begin{array}{c}\text { Parameters } \\
\text { History of similar conditions in } \\
\text { the family }\end{array}$ & Yes & 43 & $11.2 \%$ & 25 & $24.3 \%$ & \multirow{2}{*}{$\mathbf{0 . 0 0 1}$} \\
\cline { 2 - 7 } & No & 342 & $88.8 \%$ & 78 & $75.7 \%$ & \\
\hline
\end{tabular}

$\mathrm{X} 2$ : Chi-square test

There were statistically significant differences $(\mathrm{p}$-value $<0.05)$ among studied stroke patterns as regard frequency of attacks (Table 10). 
Table (10): Comparison between studied stroke patterns as regard frequency of attacks

\begin{tabular}{|c|c|c|c|c|c|c|}
\hline \multirow{2}{*}{ Parameters } & Stroke pattern & \multicolumn{2}{c|}{$\begin{array}{c}\text { Ischemic } \\
(\mathbf{N = 3 8 5})\end{array}$} & \multicolumn{2}{c|}{$\begin{array}{c}\text { Hemorrhagic } \\
(\mathbf{N = 1 0 3})\end{array}$} & \multirow{2}{*}{ P-value } \\
\hline \multirow{2}{*}{ Frequency } & First attack & 351 & $91.2 \%$ & 84 & $81.6 \%$ & \multirow{2}{*}{$\mathbf{0 . 0 0 5}$} \\
\cline { 2 - 6 } & Recurrent & 34 & $8.8 \%$ & 19 & $18.4 \%$ & \\
\hline
\end{tabular}

$\mathrm{X} 2$ : Chi-square test

\section{DISCUSSION}

The two broad categories of stroke hemorrhagic and ischemic are diametrically opposite conditions. An interruption in the flow of blood to the brain triggers ischemic strokes, whereas a blood vessel collapse or an abnormal vascular structure results in hemorrhagic strokes (Harpaz et al., 2017).

A cross sectional study was done. Total population that included in our study were suffering from acute cerebrovascular stroke at Al-Azhar University Hospitals, i.e. $78.9 \%$ of ischemic pattern and $21.1 \%$ of hemorrhagic pattern. Meta-analysis of Egyptian studies revealed that, ischemic stroke constituted $64.5 \%$, while hemorrhagic stroke constituted $35.5 \%$ of stroke (El Tallawy et al., 2015).

Regarding stroke subtypes, we reported hemorrhagic stroke in $21.1 \%$, and ischemic in $78.9 \%$. This proportion was nearly similar rates compared with Ain Shams study where it was $22 \%$ for hemorrhage and $75 \%$ for infarction (Aloush et al., 2016).

Asirvatham and Marwan,2014 reported that Saudi Arabia's most frequent subtype of stroke became ischemic infarcts (79\%), accompanied by intracerebral hemorrhage $(18.8 \%)$ and subarachnoid hemorrhage $(2.2 \%)$. Indian research reported that, relative to the other types, the frequency of ischemic stroke was higher (El Tallawy et al., 2015).

Stroke subtypes and risk factors of strokes are well known to vary widely among racial groups (blacks, whites, hispanics), and these risk-related differences may also be correlated with environmental risk factors or inherited risk factors (Boehme et al., 2017).

Age, sex, race, family history, and heredity were identified as stroke risk markers, while these factors cannot be changed. Their existence helps distinguish persons at the greatest risk of stroke and others who might profit from modifiable risk factors for prevention or aggressive therapy.

The stroke rate was more than doubling in both men and women for each consecutive 10 years after the age of 55 . The present study showed that most patients with ischemic stroke were in age group more than 60 years $(43.6 \%)$, while the majority of patients with hemorrhagic stroke were in age group between 40-60 years $(38.3 \%)$.

This age was in accordance with most of national studies, but the mean age in most western studies was higher than that in our study, It was 76,4 yrs12 and in another one (in U.K.) was 70.6 yrs (Ullberg et al., 2015, and Störk et al., 2017). 
The lower mean age of stroke patients in our study and other Egyptian studies in comparison with western studies can be clarified by the high number of population in older ages in western countries and higher prevalence of rheumatic heart diseases reported in our study that are more common in younger age populations, and also because they do tight control of risk factors like hypertension, DM and dyslipidemia.

There was a steady rise in incidence with age progression. That was in line with other stroke research that has shown that age as a risk marker for stroke has been established (Orzuza and Zurrú, 2011).

Incidence between males was greater than between females, except for the young adult category (20 to, 40 years), in which stroke incidence between females was greater than between males. In all subtypes of stroke, men have outnumbered women, and That's in line with prior epidemiological research that have shown that men are more frequently affected by stroke compared to women (Maeda et al., 2013).

Hormonal constitutional variables plus the high rate of smoking and high rate of stressful circumstances between men than women may explain this higher incidence of stroke between men (most women are housewives). The substantial prevalence of stroke in young adult women (20 to 40 years of age) could, on the other hand, be due to the pregnancy complications and labor during this childbearing period. In addition, throughout this age category, this may be linked to greater rates of migraine and/or oral contraceptive usage between women.
Positive family history was reported in $11.82 \%$ of our patients, most of those with positive family history were with ischemic stroke $72.7 \%$ vs $27.3 \%$ with positive family history of hemorrhagic stroke. Our study showed very significant statistical difference between both study groups as regard marital status. Majority of patients with ischemic stroke and hemorrhagic stroke were married $(65.2 \%$ and $92 \%$ respectively).

Prior research have looked at the health effects of important cause life events, such as the death of a spouse, kids, siblings and/or parents. One research examined the possible impacts on the risk of cardiac arrest of such main life events, like separations from a near member of the family, the departure of a member of the household, the transfer of a new member of the household or the relocation of a member of residence. The risk of stroke and its types has not yet been studied (Maeda et al., 2013).

A study found that the marital transition, known as a shift in marital status over a given period, was correlated with the risk of stroke in Japanese women and men, and that the correlations were changed by accompanying shifts in living arrangement, while there are two types of marital transition, this research only discussed the marital transition from married to unmarried (Maeda et al., 2013).

Active smoking of cigarette has long been identified as a significant risk factor for stroke with multifactorial pathophysiological impacts, including increased hematocrite, increased fibrinogen level, increased platelet aggregation, increased arterial wall 
stiffness and decreased high density lipoproteins (Mackawy and Badawy, 2011).

As regard special habits status, our study indicated substantial statistical differences between both study groups and majority of patients with ischemic stroke were smokers $(55.8 \%)$, while only $42.7 \%$ hemorrhagic stroke were smokers. With a strong dose-response relationship, cigarette smoking raised almost twice the threat of an ischemic stroke. The smoking of cigarettes as a threat factor for subarachnoid hemorrhage is reported, while in intracerebral hemorrhage its risk is postulated by some hypotheses including elevation of proteolytic enzyme activity released by macrophages in the lung with liability for aneurysms formation and elevation of blood pressure with use of nicotine (Ghahremanfard et al., 2015).

Our results were higher than other national studies, where smoking reported in $33.3 \%$ of stroke patients, in Egyptian met analysis smoking reported in 36.1\% and also in NOMASS smoking reported in $36.7 \%$ of stroke patients (Malik et al., 2019).

Heart diseases are known to be a stroke risk factor. Relative to those who do not have the disease. Individuals with atrial fibrillation were about 5 times more probable to suffer from strokes. Individuals with chronic heart failure or coronary heart disease were around 2 to 4 times more probable to be stroke-related. In this research, $27.1 \%$ of stroke patients experienced heart disease (La Cámara et al., 2013).

We reported that $57.1 \%$ of cases had history of hypertension within ischemic stroke group compared with $65 \%$ of cases within hemorrhagic stroke. Our results agreed that reported in some studies, e.g. in Ain shams study hypertension reported in $67 \%$ of stroke patients, in USA, NOMASS reported in $54.3 \%$ and in metaanalysis of eight national studies reported in $67.1 \%$, while other studies reported lower rates of hypertension $31 \%$ and $32 \%$ (Sweden), while it was the same in another study (U.K) (Malik et al., 2019).

Our results also agreed with most of previous studies which reported hypertension to be more in hemorrhagic stroke.

The single most relevant modifiable risk factor for stroke is hypertension, which is considered a significant risk factor for both hemorrhage and infarction. When hypertension is characterized as systolic $\geq 160 \mathrm{mmHg}$ and/or diastolic $\geq 95$ $\mathrm{mmHg}$, most estimates for high blood pressure imply a relative risk of stroke of approximately 4 (Mackawy and Badawy, 2011).

Hypertension has the same effect on stroke mortality as on stroke incidence that it was reported in our as in other studies. Therefore, measures that have been shown to control blood pressure will reduce hypertension related stroke risk as well as fatal stroke and consequent disabilities (Arboix, 2015).

The mechanism by which cerebrovascular auto regulation is altered by high blood pressure is not fully known, but is probably to involve a combination of impacts on myogenic tone and shifts in the mechanical properties of cerebrovascular blood vessels triggered by remodeling and stiffening. The periventricular white matter, that is 
situated at the boundary among various arterial territories and is therefore most vulnerable to hypoperfusion, is especially damaged by these changes in autoregulation (Faraco and Iadecola, 2013).

High risk factors for coronary heart disease are increasing levels of total plasma cholesterol and low-density lipoprotein cholesterol and declining level of high-density lipoprotein cholesterol, while the relation between risk of blood lipids and stroke is much weaker (Sun et al., 2014). Studies, however, have clarified the association among lipids and stroke, as well as indicating that cholesterol-lowering drugs can decrease the risk of stroke and carotid atheroma. On the other hand, an opposite correlation was reported among total cholesterol and cerebral hemorrhage (Ravnskov et al., 2016).

In the present study, hyperlipidemia reported in $83 \%$ of cases no history of hyperlipidemia within ischemic stroke group compared with $94 \%$ of cases within hemorrhagic stroke with no definite causal relationship with stroke subtypes can be defined.

Regarding incidence of hyperlipidemia in stroke in general, there is much discrepancy between different studies, where Ain Shams study reported incidence of $34.9 \%$ for dyslipidemia and in Egyptian meta-analysis three studies dyslipidemia was reported in $57.9 \%$. Western studies showed also much variations where some studies reported higher results as $41 \% 58$, while others reported much lower results as $2.1 \% 69$, and $4.6 \%$ (Abd-Allah et al., 2018).
Cholesterol and stroke are difficult to relate, since their relation varies depending on the type of stroke and the type of cholesterol included. Individuals with the highest non-high-density lipoprotein tertile to high-density lipoprotein ratio will have an elevated risk of ischemic stroke relative to those with the lowest tertile (Rist et al., 2019).

The present study showed that all cases within ischemic stroke group had no history of Hepatic diseases, while $10.7 \%$ of cases within hemorrhagic stroke had history of Hepatic diseases with highly significant statistical difference between both study groups as regard Hepatic disease.

Umebayashi et al., (2010) assessed liver function and parameters of coagulation in sufferers with spontaneous intracerebral hemorrhage who were referred to their clinic inside $24 \mathrm{hrs}$ after onset. Fibrinogen concentration was abnormally low and in one, at the lower end of the normal range. Two-showed thrombocytopenia indicated prolonged prothrombin time in one case. Suggest that liver disorders produce a hemorrhage condition that happens more quickly, and one of the potential causes of spontaneous intracerebral hemorrhage may be this hemorrhagic tendency.

An elevated risk of stroke, especially hemorrhagic stroke, was correlated with cirrhosis in a nationally representative sample of Medicare beneficiaries. The mixed coagulopathy found in cirrhosis is a possible cause of these results (Parikh et al., 2017).

In terms of vomiting, seizures, impaired consciousness, and sphincteric disturbances, our research showed 
substantial statistical differences among both study groups.

In this research, headache was registered in $68.3 \%$ of sufferers that was comparable to that in the research by Rymer (2011) who recorded headache in $60 \%$ and vomiting in $75 \%$ of sufferers. Headache, vomiting, and vertigo have been shown to be substantially more frequent hemorrhagic stroke accompaniments than other stroke types, that is consistent.

Cerebrovascular disease was the most frequently reported etiology in sufferers with symptomatic epilepsy in a large epidemiological project. It is suspected that early post-stroke seizures (inside of 15 days of stroke) arise from cellular biochemical dysfunction, contributing to electrically irritable tissues, whereas gliosis and the development of a meningocerebral cicatrix are supposed to induce late-onset seizures. In the present research, seizures were recorded in $27.8 \%$ of sufferers, a ratio that became higher than ischemic stroke $(24.2 \%)$ between sufferers with hemorrhagic stroke $(41.7 \%)$ and higher than the rate found in the prospective multicenter report $(8.6 \%)$ from the "Seizure After Stroke Study Group" (Pattabi et al., 2011 and El Tallawy et al., 2015).

At a greater rate $(33 \%)$ of sufferers with hemorrhagic stroke than ischemic stroke $(22.1 \%)$, impaired consciousness was registered, which is in line with the preceding study. In sufferers with hemorrhagic stroke, this high rate of diminished consciousness may be due to a substantially greater consequent rate of elevated intracranial tension compared to an ischemic stroke in sufferers with a hemorrhagic stroke (Rymer, 2011).

The most common appearance of stroke was hemiparesis and hemiplegia (94.8\%). That was in accordance with Rymer (2011) who noticed that hemiplegia $(80 \%)$ was the most common clinical characteristic in India at presentation of stroke, accompanied by aphasia (59\%) and dysarthria (60\%). Patients experienced less speech defects in the present research $(25.8 \%$ for Dysphasia and $91.3 \%$ for dysarthria). This variation may be due to the type of study, i.e. prospective or retrospective study such as the current one (Baidya et al., 2013).

In comparison to other research, 56.1 $\%$ had right-sided lesions with respect to the side of the lesion that showed that left hemisphere brain infarction was more frequent than right-sided lesions. Our study showed significant statistical difference between both study groups as regard Side of Hemiplegia.

The cumulative probability of stroke recurrence varies among $15 \%$ and $40 \%$ within 5 years following the first episode. Advancing age, high blood pressure, atrial fibrillation, diabetes mellitus, hyperlipidemia, and prior TIA are the most important predictive of stroke recurrence found in epidemiological trials. In this research, $10.8 \%$ had a prior stroke.

\section{CONCLUSION}

There was a steady increase with advancing age. Overall, males predominated except in age $<35$ years with female predominance. Positive family history reported more in ischemic strokes. Married participants showed higher incidence of ischemic and 
hemorrhagic strokes. Smoking was more in ischemic strokes. In ischemic strokes, hyperlipidemia was recorded more, but with no clear causal association with subtypes of stroke. History of recurrent strokes reported more with ischemic strokes.

Diabetes mellitus reported more with ischemic strokes, same as cardiac diseases were more in ischemic strokes, also hypertension reported more with ischemic strokes, while Hepatic disease reported more with hemorrhagic strokes. Seizures (Generalized rather than Focal), vomiting, diminished consciousness, and sphincteric disorders were found to be significantly more common clinical presentations of our patients.

Stroke epidemiology was rapidly changing, and the global burden of stroke continues to rise globally. There was also an important call to raise public awareness and to incorporate stroke treatments and their risk factors and symptoms to assist people recognize and ultimately avoid the harmful effect of stroke on the life quality.

\section{REFERENCES}

1. Abbott AL, Silvestrini M, Topakian R, Golledge J and Brunser AM (2017): Optimizing the Definitions of Stroke, Transient Ischemic Attack, and Infarction for Research and Application in Clinical Practice. Front Neurol., 8:537-539.

2. Abd-Allah F, Khedr E, Oraby MI, Bedair AS and Georgy SS (2018): Stroke burden in Egypt: data from five epidemiological studies. Int J Neurosci., 128:765-771.

3. Aloush TK, Fahmy NA, Elaidy DA and Abdel-Baki RS (2016): Site and degree of intracranial arterial stenosis in acute stroke patients with metabolic syndrome among a sample of Egyptian patients. The Egyptian Journal of Neurology, Psychiatry and Neurosurgery, 53(2):89-91.
4. Arboix A (2015): Cardiovascular risk factors for acute stroke: Risk profiles in the different subtypes of ischemic stroke. World J Clin Cases., 3:418-420.

5. Asirvatham AR and Marwan MZ (2014): Stroke in Saudi Arabia: a review of the recent literature. Pan African Medical Journal, 17(1): 89-94.

6. Baidya OP, Chaudhuri S, Gomti Devi $\mathrm{K}$ and Devi KG (2013): Clinicoepidemiological study of acute ischemic stroke in a tertiary hospital of northeastern state of India. Int J Biomed Adv Res., 4:661665 .

7. Boehme AK, Esenwa C and Elkind MS (2017): Stroke risk factors, genetics, and prevention. Circulation research, 120(3):47295.

8. El Tallawy HN, Farghaly WM, Badry R, Hamdy NA, Shehata GA, Rageh TA, Metwally NA, Hassan EM, Elsayed SS, Yehia MA and Soliman WT (2015): Epidemiology and clinical presentation of stroke in upper egypt (Desert area). Neuropsychiatr Dis Treat., 11:2177-2183.

9. Fang MC, Marcelo Coca P, Perraillon MC, Ghosh K, Cutler DM and Rosen AB (2014): Trends in Stroke Rates, Risk, and Outcomes in the United States, 1988 to 2008 The American Journal of Medicine, 127: 608615.

10. Faraco $G$ and Iadecola $C$ (2013): Hypertension: A harbinger of stroke and dementia. Hypertension, 62:810-817.

11. Feigin VL, Roth GA, Naghavi M, Parmar $P$, Krishnamurthi R, Chugh S, Mensah GA, Norrving B, Shiue I, Ng M and Estep K (2016): Global burden of stroke and risk factors in 188 countries, during 1990-2013: a systematic analysis for the Global Burden of Disease Study 2013. Lancet Neurol., 15:913924.

12. Fu GR, Yuan WQ, Du WL, Yang ZH, Fu N, Zheng HG, Li ZX, Huang YM, Zhang YM, Dai GZ and Wang HB (2015): Risk Factors Associated with Recurrent Strokes in Young and Elderly Patients: A Hospitalbased Study. Int J Gerontol., 9:63-66. 
13. GBD Lifetime Risk of Stroke Collaborators (2018): Global, regional, and country-specific lifetime risks of stroke, 1990 and 2016. New England Journal of Medicine, 379(25):2429-37.

14. Ghahremanfard F, Semnani V, Ghorbani R, Malek F, Behzadfar A and Zahmatkesh M (2015): Effects of cigarette smoking on morphological features of platelets in healthy men. Saudi Med J., 36:847-850.

15. Gray JM, Rasanayagam S, Engel $C$ and Rizzo J (2017): State of the evidence 2017: an update on the connection between breast cancer and the environment. Environ Health, 16:94-99.

16. Harpaz D, Eltzov E, Seet RCS, Marks RS and Tok AI (2017): Point-of-care-testing in acute stroke management: An unmet need ripe for technological Harvest. Biosensors, 7:30-33.

17. Hong KS, Yegiaian S, Lee $M$, Lee $J$ and Saver JL (2011): Declining stroke and vascular event recurrence rates in secondary prevention trials over the past 50 years and consequences for current trial design. Circulation, 123:2111-2119.

18. Isaacs EB (2013): Neuroimaging, a new tool for investigating the effects of early diet on cognitive and brain development. Front Hum Neurosci., 7:445-449.

19. Kernan W, Ovbiagele B, Black H, Bravata DM, Chimowitz MI, Ezekowitz MD, Fang MC, Fisher M, Furie KL, Heck DV and Johnston SC (2014): Guidelines for prevention of stroke in patients with stroke and transient Ischemic attack: guideline for healthcare professionals from American Heart Association/ American stroke Association. Stroke, 45: 2160-2236.

20. Krishnamurthi RV, Valery LF, Mohammad HF, Feigin VL, Forouzanfar MH, Mensah GA, Connor M, Bennett DA, Moran AE, Sacco RL, Anderson LM, Truelsen $T$ and O'Donnell $M$ (2013): Global and regional burden of first-ever ischaemic and haemorrhagic stroke during 1990-2010: findings from the Global Burden of Disease Study 2010 Lancet Glob Health, 1(5):e259-81.
21. La Cámara A, Arche $J$, Vivas $P$ and Ferrando P (2013): Recurrence after a Firstever Ischemic Stroke Development of a Clinical Prediction Rule. Res Neurol An Int J., 1-13.

22. Mackawy AM and Badawy M (2011): Methylene tetrahydrofolate reductase gene polymorphism and the risk of ischemic stroke in type 2 diabetic Egyptian patients. Global Journal of Health Science, 3(2):162-168.

23. Maeda $K$, Toyoda $K$, Minematsu $K$ and Kobayashi S (2013): Effects of sex difference on clinical features of acute ischemic stroke in japan. $J$ Stroke Cerebrovasc Dis., 22:1070-1075.

24. Malik MA, Hussain A, Mustafa J, Nasim N and Asghar $S$ (2019): Frequency of Dyslipidemia in Hemorrhagic Stroke. Annals of Punjab Medical College, 13(3):229-31.

25. Mozaffarian D, Benjamin EJ, Go AS, Arnett DK, Blaha MJ, Cushman M, Das SR, De Ferranti S, Després JP, Fullerton HJ and Howard VJ (2016): Heart Disease and Stroke StatisticsV2016 Update: a report from the American Heart Association. Circulation, 133(4):e38Ye60.

26. Ogden CL, Carroll MD, Kit BK and Flegal KM (2012): Prevalence of obesity and trends in body mass index among US children and adolescents, 1999-2010. JAMA, 307:483490.

27. Orzuza G and Zurrú MC (2011): Epidemiological aspects of stroke in very old patients. Cardiovasc Hematol Disord Drug Targets, 11:2-5.

28. Parikh NS, Navi BB, Schneider Y, Jesudian A and Kamel H (2017): Association between cirrhosis and stroke in a nationally representative cohort. JAMA Neurol., 74:927-932.

29. Pattabi M, Gurumurthy SC, Sanjeev G and Gaikwad AB (2011): Morphological changes in nanoparticulate silver films due to electron beam irradiation of polystyrene substrates. Nucl Instruments Methods Phys Res Sect B Beam Interact with Mater Atoms, 269:1534-1539. 
30. Prentice RL, Aragaki AK, Van Horn L, Thomson CA, Beresford SA, Robinson J, Snetselaar L, Anderson GL, Manson JE, Allison MA and Rossouw JE (2017): Lowfat dietary pattern and cardiovascular disease: results from the Women's Health Initiative randomized controlled trial. The American Journal of Clinical Nutrition, 106(1):35-43.

31. Ravnskov U, Diamond DM, Hama R, Hamazaki T, Hammarskjöld B, Hynes N, Kendrick M, Langsjoen PH, Malhotra A, Mascitelli L and McCully KS (2016): Lack of an association or an inverse association between low-density-lipoprotein cholesterol and mortality in the elderly: A systematic review. BMJ Open, 6: 10-14.

32. Rist PM, Buring JE, Ridker PM, Kase CS, Kurth T and Rexrode KM (2019): Lipid levels and the risk of hemorrhagic stroke among women. Neurology, 92(19):e2286-94.

33. Rymer MM (2011): Hemorrhagic stroke: intracerebral hemorrhage. Missouri medicine, 108(1):50-56.

34. Störk S, Handrock R, Jacob J, Walker J, Calado F, Lahoz R, Hupfer $S$ and Klebs $S$ (2017): Treatment of chronic heart failure in
Germany: a retrospective database study. Clin Res Cardiol., 106:923-932.

35. Sun GZ, Li Z, Guo L, Zhou Y, Yang HM and Sun YX (2014): High prevalence of dyslipidemia and associated risk factors among rural Chinese adults. Lipids Health Dis., 13:189-191.

36. Ullberg T, Zia E, Petersson $J$ and Norrving B (2015): Changes in functional outcome over the first year after stroke: an observational study from the Swedish stroke register. Stroke, 46(2):389-94.

37. Umebayashi D, Mandai A, Osaka Y, Nakahara $Y$ and Tenjin H (2010): Effects and complications of stereotactic aspiration for spontaneous intracerebral hemorrhage. Neurologia Medico-Chirurgica., 50(7):53844. 


\section{أنماط السكتة الدماغية بمستشفيات جامعة الأز هر محمود محمد عبد الجواد حسين، محمد البهي محمد جمال، أحمد عصمت علي قسم الأمراض العصبية، كلية الطب، جامعة الأزهر}

\section{E-mail: $\underline{\text { drmahmoud.ghozzy@gmail.com }}$}

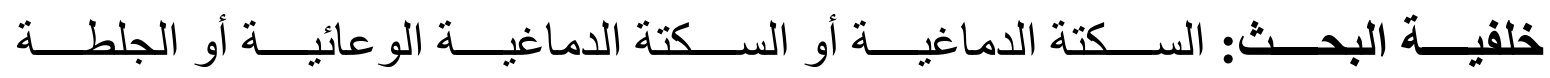

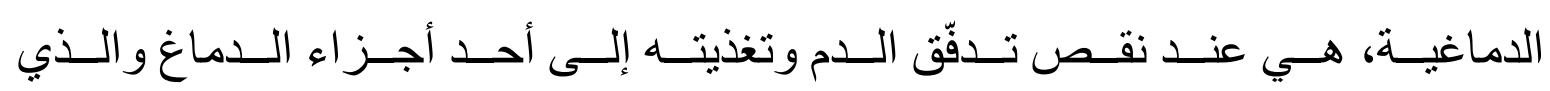

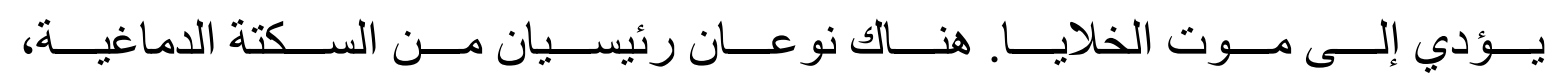

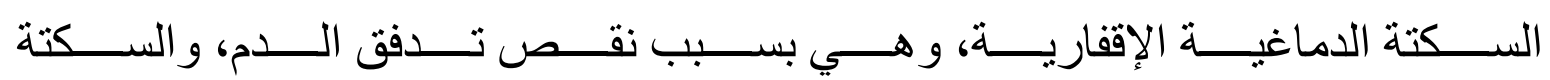
الدماغية النزفية، وهي بسبب النزيف الدماغي.

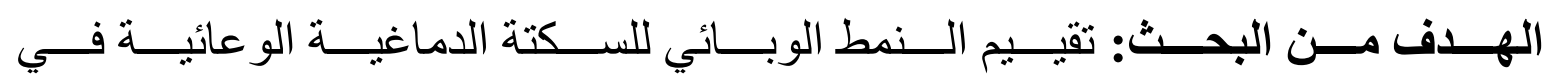

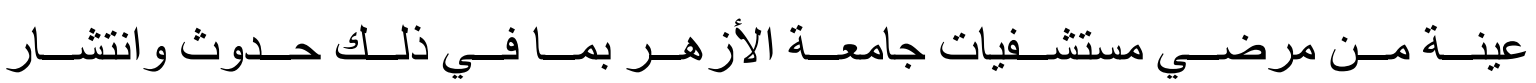
السكتة الدماغية وأنو اعها الفرعية المختلفة (نقص التروية والنزيف).

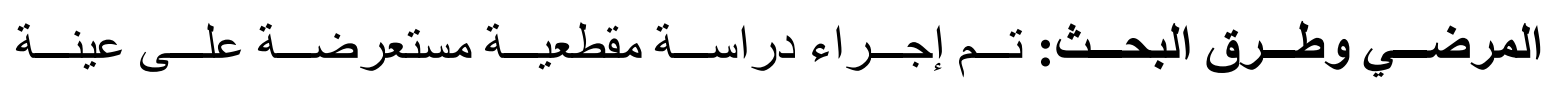

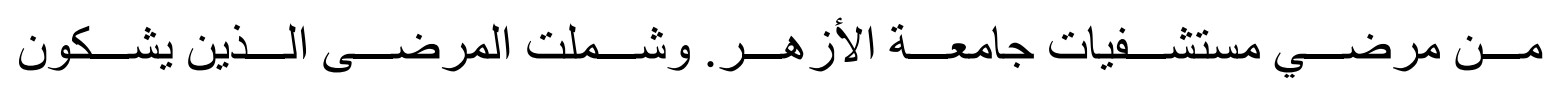

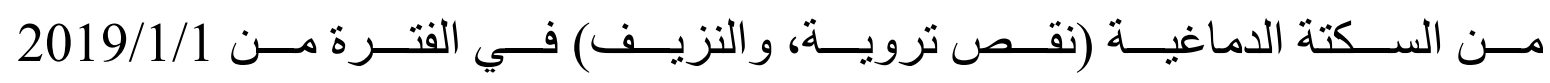

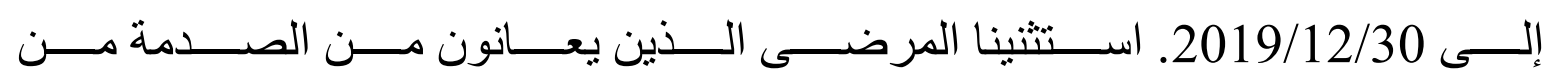

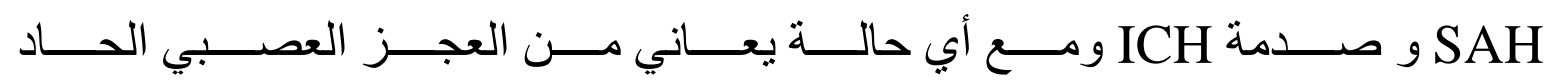

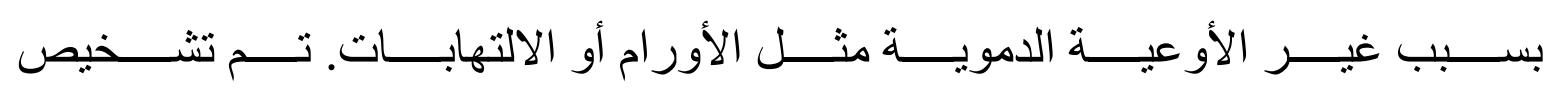

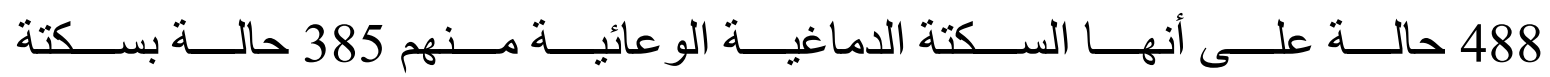
إقفارية تمثل 78.9\%، و 103 حالة بسكتة دماغية نزفية تمثل 21.1\% نتـــائج البحـــث: مــن حيـــث الحالـــة الاجتماعيـــة، و أمــــر اض الكبـــد، وكـــللك

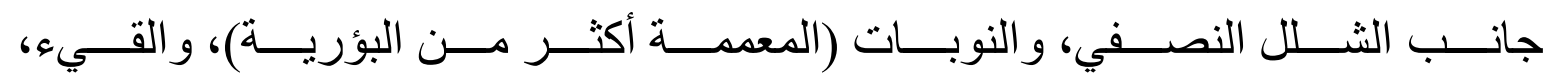




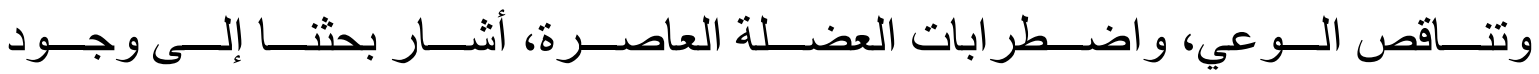
فروق ذات دلالة إحصائية بين مجمو عتي الدراسة.

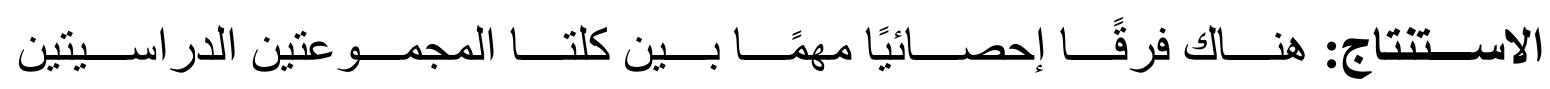

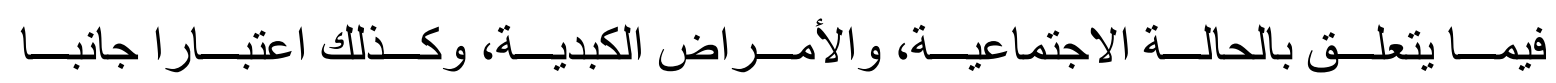

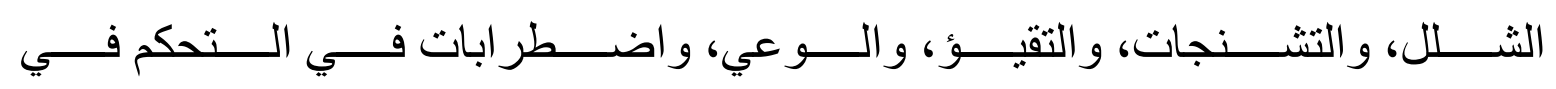
التبول و التبرز.

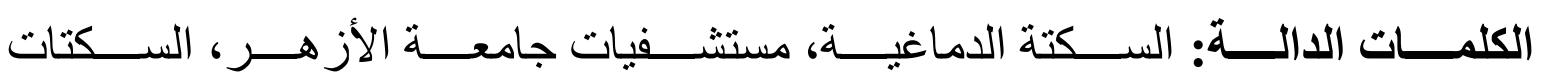
الدماغية الو عائية، نقص التروية. 